\title{
Emergency department-based cancer screening interventions
}

\author{
David Adler ${ }^{1 *}$ (D, Beau Abar ${ }^{1}$ and Elizabeth Yu Chiao ${ }^{2}$
}

\begin{abstract}
Background: Emergency department patients are disproportionately non-adherent with the United States Preventive Services Task Force cancer screening recommendations, making the emergency department a target-rich environment for interventions aimed at increasing the uptake of cancer screening. Promotion of cancer screening in the emergency department has the potential to address health disparities and to reach patients that experience significant barriers to accessing preventive care.

Topics of review: This narrative review presents concise summaries of the four types of cancer screenings with grade A or B recommendations from the United States Preventive Services Task Force (breast, cervical, colorectal, and lung) and presents the potential enabling factors and challenges of utilizing the emergency department setting to increase cancer screening uptake. Past and ongoing efforts to promote cancer screening among emergency department patients are discussed, and critical knowledge gaps and research opportunities are highlighted.

Conclusion: Although there has been a paucity of research evaluating interventions that have the potential to increase cancer screening uptake among emergency department patients, the emergency department setting is uniquely positioned to address disparities in cancer screening uptake and contribute to progress towards national cancer screening goals. To be effective, interventions that aim to achieve this purpose must identify patients with screening needs, engage with patients regarding their knowledge and beliefs about screening, and provide an effective method to conduct or connect patients with screening procedures and subsequent follow-up.
\end{abstract}

Keywords: Emergency department, Breast cancer screening, Cervical cancer screening, Colorectal cancer screening, Lung cancer screening, Health disparities

\section{Background}

Recommended cancer screenings aim to identify precancerous lesions that can be removed prior to the development of cancer, and early-stage cancerous lesions that can be effectively treated prior to the development of advanced cancer. There are significant disparities, however, in the uptake of cancer screening based on race, ethnicity, income, level of education, and access to care [1-12].

\footnotetext{
* Correspondence: David_adler@urmc.rochester.edu

'Department of Emergency Medicine, University of Rochester, 601 Elmwood Avenue, Box 655C, Rochester, NY 14642, USA

Full list of author information is available at the end of the article
}

These risk factors for non-adherence with recommended cancer screenings are disproportionately present among emergency department (ED) patients [11, 13-17]. EDs provide universal access points to the healthcare system where there are 40 visits per year for every 100 people in the USA [18]. Although EDs care for patients from all segments of society, people who experience barriers to accessing healthcare are over-represented in the ED setting where health inequities are pronounced [11, 13-16, 19-21].

The United States Public Health Service recommends that all patient encounters be used to provide preventive healthcare to patients [22]. With approximately 130 million patient visits per year [23], and a patient population

(c) The Author(s). 2022 Open Access This article is licensed under a Creative Commons Attribution 4.0 International License, which permits use, sharing, adaptation, distribution and reproduction in any medium or format, as long as you give appropriate credit to the original author(s) and the source, provide a link to the Creative Commons licence, and indicate if changes were made. The images or other third party material in this article are included in the article's Creative Commons licence, unless indicated otherwise in a credit line to the material. If material is not included in the article's Creative Commons licence and your intended use is not permitted by statutory regulation or exceeds the permitted use, you will need to obtain permission directly from the copyright holder. To view a copy of this licence, visit http://creativecommons.org/licenses/by/4.0/.
} 
disproportionately non-adherent with cancer screening, the ED is an environment with significant potential to identify individuals with cancer screening needs, especially those who are hard to reach through other healthcare settings, and intervene to catalyze the uptake of cancer screenings. Interventions of this nature should always be designed to minimize burden on clinicians and ED flow, but this restriction does not preclude effectiveness. Numerous other preventive health needs have been successfully addressed in the ED including smoking cessation, alcohol use disorder, substance abuse, HIV testing, and depression screening [24-30].

There are four cancer screenings that have grade A or B recommendations from the United States Preventive Services Task Force (USPSTF): cervical [31], breast [32], colorectal [33], and lung [34]. Each has specific eligibility criteria based on age, sex, and, in the case of lung cancer screening, smoking history. Unfortunately, screening rates for each of these cancers remain below the federal government's Healthy People 2020 and 2030 targets [10, 35-37]. According to the 2018 National Health Interview Survey (NHIS), rates of breast and cervical cancer screening have not significantly improved since 2005 [10]. Colorectal cancer screening has improved over recent years, although only $66.9 \%$ of eligible adults are up-to-date with recommended screening [10]. Lung cancer screening rates are abysmal with only $14.4 \%$ of eligible patients found to have been screened in a recent 10 state study [35]. As mentioned above, these general population rates elide significant screening disparities among subgroups.

In a 2020 analysis of NHIS data that sought to estimate the number of patients in need of a cancer screening who also had at least one ED visit in the preceding year, researchers found that more than 14 million, 6 million, and 2 million ED patients were in need of breast, colorectal, or lung cancer screening, respectively [38]. These data underscore the ED's position as a target-rich environment to promote adherence with USPSTFrecommended cancer screenings, especially among hardto-reach groups, and to advance progress towards Healthy People 2030 goals.

This narrative review presents the potential and challenges of utilizing the ED setting to increase cancer screening uptake. Past and ongoing efforts to promote cancer screening among ED patients are discussed, and critical knowledge gaps and research opportunities are highlighted. Given the emphasis on US-based screening recommendations, surveillance data, and ED operations, applicability to settings outside of the USA may be limited.

\section{USPSTF-recommended cancer screenings Breast cancer screening}

Breast cancer is the most commonly diagnosed cancer among women in the USA (excluding skin cancers) and is second only to lung cancer in cancer-related attributable deaths among women (estimated 43,600 deaths in 2021) $[39,40]$. The USPSTF provides a grade B recommendation for biennial breast cancer screening using mammography for women between the ages of 50 and 74 years [41]. Importantly, there are a variety of patient and family history characteristics that can impact the benefit associated with mammography among women 40 to 49 years of age (e.g., family history of breast cancer, genetic risk associated with breast cancer such as BRCA-1/2 mutations), though the negative effects of testing and false-positive findings tend to offset this benefit. As such, the USPSTF offers a grade $\mathrm{C}$ recommendation ("at least fair evidence that [the service] can improve health outcomes but concludes that the balance of benefits and harms is too close to justify a general recommendation") for regular screening mammography in this age range.

Identification and mortality associated with breast cancer are significantly associated with patient demographic characteristics [39]. Breast cancer among White women is identified when localized $64 \%$ of the time and only $54 \%$ of the time for Black women. While there is some evidence that this difference is attributable to socioeconomic status [42], other findings implicate lower screening rates [43]. The overall rate of screening adherence in the USA in 2018 was $72.8 \%$, with the Healthy People 2030 initiative targeting an increase to $77.1 \%$.

\section{Cervical cancer screening}

Cervical cancer is among the most preventable forms of cancer. Screening for cervical cancer aims to identify treatable pre-cancerous lesions prior to the development of invasive cancer which is often first detected at a stage when palliation is all that can be offered. The USPSTF recommends cervical cancer screening with a Papanicolaou (Pap) test for women aged 21-65 every 3 years with a possible extension of this screening interval to every 5 years with high-risk human papillomavirus (HPV) DNA testing or co-testing for women aged 30-65 [31]. For women at increased risk of cervical cancer (e.g., women living with HIV), screening recommendations differ from these general guidelines.

It has recently been reported that cervical cancer mortality rates in the USA are higher than previously thought and that there is a significant racial disparity in cervical cancer death rates [5]. The mortality rate for Black women was found to be 10.1/100,000 compared to 4.7/100,000 for White women [5]. The CDC's most recent survey of adherence to USPSTF cervical cancer screening recommendations found that only $80.7 \%$ of US women aged 21-65 years reported adherence [13]considerably below the Healthy People 2020 target of 93\% [36]. The CDC found the very lowest rates of 
adherence to cervical cancer screening guidelines among women using the ED as their usual source of care [13].

\section{Colorectal cancer screening}

Colorectal cancer (CRC) is diagnosed in nearly 150,000 adults in the USA annually, making it the 3rd most common cancer found in both men (9\% of new cases) and women (8\% of new cases) [44]. Approximately 53,200 deaths are attributed to colorectal cancer annually, with early detection playing a key role in survival [45-48]. The 5-year survival rate for colorectal cancer is $89 \%$ when identified locally and $15 \%$ when identified with distal spread.

The USPSTF offers a grade A recommendation for regular CRC screening from age 50 to 75 [49] and a grade $\mathrm{B}$ recommendation (i.e., "high certainty that the net benefit is moderate or...moderate certainty that the net benefit is moderate to substantial") for CRC screening between ages 45 and 49. Colorectal screening adherence involves (a) a colonoscopy every 10 years, (b) flexible sigmoidoscopy every 5 years, (c) CT colonography every 5 years, (d) annual fecal occult blood test (FOBT) or fecal immunochemical test (FIT) [50], or (e) screening of DNA in the stool (e.g., Cologuard) every 1 to 3 years $[48,50,51]$. Unfortunately, only $65.2 \%$ of adults were adherent with USPSTF screening recommendations in 2018, with the Healthy People 2030 initiative calling for rates (now on a broader patient population) to reach $74.4 \%$. Furthermore, ethnic and racial disparities in screening adherence similar to those seen for breast and cervical cancer have previously been observed [52, 53], again implying the ED is an ideal setting for intervention.

\section{Lung cancer screening}

Lung cancer is the number one cancer cause of death in the USA [54], accounting for a quarter of all cancer deaths [55]. Five-year survival for lung cancer is just 19\% [6]. However, early detection of lung cancer increases 5year survival threefold [6], and lung cancer screening among high-risk patients, using a low-dose CT scan, is cost-effective [56] and has been proven to reduce lung cancer mortality by approximately $20 \%$ [57, 58]. In March 2021, the USPSTF expanded eligibility for lung cancer screening to patients aged $50-80$ with $\geq 20$ packyear smoking history [34]. Objective C-03 of the Healthy People 2030 initiative is to "increase the proportion of adults who get screened for lung cancer" [37].

Disparities in lung cancer and lung cancer screening are marked in the USA with less economically advantaged and less educated populations at higher risk of disease but with less access to screening services [6]. Racial disparities are particularly prominent: the burden of lung cancer falls disproportionately on black individuals- especially black males, who have the highest rate of age-adjusted lung cancer incidence of all groups, are more likely to present at an advanced stage of disease, and are more likely to die $[6,59,60]$. Unfortunately, uptake of lung cancer screening has been poor [35]. In July 2020, USPSTF listed "research addressing how to best increase uptake of lung cancer screening ... particularly among minority and vulnerable populations" as a top priority [61].

\section{Enabling factors of the ED setting}

Although EDs are designed to treat acute illnesses and injuries, certain characteristics of the ED setting have the potential to facilitate cancer screening interventions. While in a healthcare setting, patients may have a heightened awareness of health risks and health-related behaviors. This may allow for increased receptivity to a preventive health intervention. The "teachable moment" that may occur in the ED is an opportunity to increase the impact of such interventions [62]. Indeed, a number of investigations support the notion that ED patients are receptive to preventive health measures. A survey of over 1200 consecutive ED patients found that $96 \%$ reported interest in receiving information on one or more preventive health issues [63]. Similarly, in a pilot study evaluating the feasibility of promoting mammography among ED patients, $75 \%$ of women reported receptivity to the proposed intervention [64]. ED patients have also been found to readily engage with computerized preventive health education resources while waiting for care [65].

Wait time is another potentially enabling factor of the ED setting. Patients not only wait in the waiting room prior to full evaluation by a provider, they also spend a significant amount of time waiting in treatment areas for radiologic studies to be completed, test results to become available, and evaluations by specialists. This "down time" provides an opportunity to identify cancer screening needs and intervene to address them without impacting the length of stay. High acuity ED patients, patients in significant distress, and patients with an altered level of consciousness are poor candidates for preventive health interventions. However, many ED patients are low to moderate in acuity, and lower acuity ED visits are common among patients with barriers to care and those at increased risk for non-adherence with cancer screening recommendations [66].

ED directors are also in favor of ED-based preventive health services that do not increase the patient length of stay or take clinician time away from other patients [67]. Still, in a field with a seemingly never-ending expansion of responsibilities, concern about mission creep is very real [68]. Ideally, cancer screening needs are identified by primary care providers and then scheduled as needed. However, among patients that lack ready access to 
primary care due to under-insurance or other barriers, the ED remains the safety net for healthcare system failures. Patients subjected to these system failures are from the precise hard-to-reach groups that are most in need of cancer screening. The provision of preventive care in the ED can be viewed as a diversion of resources that should rightfully be directed towards those with acute illness and injury. However, a significant amount of the acute illness cared for in the ED could have been prevented had access to primary care and preventive health services been sufficient. Thoughtful interventions designed with provider input have the potential to achieve meaningful preventive outcomes while minimizing the impact on clinical operations.

\section{Identifying eligibility and need}

The first step to increasing uptake of cancer screening among ED patients is to identify those patients who are eligible for screening. Each of the four USPSTF grade A/ B screenings has different but potentially overlapping eligibility criteria (Table 1). In addition, just because someone is eligible does not mean they are in need of screening-some patients will be up-to-date with cancer screening recommendations. Over-referral or overscreening would be an unintended negative consequence of a cancer screening intervention that failed to accurately assess screening needs.

Determination of screening adherence, therefore, is a necessary second step to identify candidates for an EDbased cancer screening intervention (Fig. 1). While the process of determining screening eligibility and adherence seems straightforward, it is potentially labor intensive. The ED triage process is already burdened with extensive screening questions including topics such as fall risk, intimate partner violence, elder abuse, and risks associated with international travel. Adding a series of surveys to evaluate cancer screening needs is not likely feasible. A number of studies have succeeded in using non-physician staff to survey patients and determine their screening needs $[2,11,15,69]$. While some EDs may have research associates, volunteers, patient care technicians, or other staff available to do this work, many will not.

An ongoing study funded by the National Cancer Institute is evaluating an adaptive self-administered process using a tablet computer to determine cancer screening needs in order to relieve staff of this burden [70]. A more generalized health risk computerized survey, evaluating issues such as substance abuse and immunizations, was successfully deployed in an ED nearly 20 years ago [71]. A "smart" electronic health record (EHR) could potentially flag patients with screening needs although confirmation by staff would likely still be necessary.

\section{ED-based screening interventions}

Despite the potential of the ED setting to catalyze the uptake of cancer screening, few interventions attempting to do so have been evaluated.

\section{In-ED cancer screening}

While some cancer screening procedures could conceivably be done in the ED (e.g., Pap tests for cervical cancer, low-dose CT scan for lung cancer, FIT and/or stool DNA testing for colorectal cancer), others are plainly not feasible (e.g., colonoscopy). Precious little work has been done in this area, all of it related to Pap tests, and much of it more than two decades ago. In all cases, these studies only conducted Pap tests on women already undergoing pelvic exams to evaluate the complaint that brought them to the ED [72-76]. This conveniencebased approach would not address the cervical cancer screening needs of most ED patients. Still, the investigators behind some of this work did specifically report that high-quality Pap specimens were successfully obtained in the ED, supporting at least one aspect of feasibility

Table 1 USPSTF cancer screening eligibility criteria and intervals

\begin{tabular}{|c|c|c|c|}
\hline Cancer & Patient population $^{a}$ & Screening test(s) & Recommended screening interval(s) \\
\hline Breast & Women age $50-74$ years & Screening mammogram & Every 2 years \\
\hline Cervical & Women age $21-65$ years & $\begin{array}{l}\text { Papanicolaou (Pap) test } \\
\text { High-risk human papillomavirus (hrHPV) test } \\
\text { Pap and hrHPV tests (co-testing) }\end{array}$ & $\begin{array}{l}\text { Every } 3 \text { years } \\
\text { Every } 5 \text { years (age 30-65 only) } \\
\text { Every } 5 \text { years (age 30-65 only) }\end{array}$ \\
\hline Colorectal & Age $45-75$ years & $\begin{array}{l}\text { Colonoscopy } \\
\text { Sigmoidoscopy } \\
\text { Fecal occult blood tests } \\
\text { Fecal immunochemical tests } \\
\text { CT colonography } \\
\text { Stool DNA tests (e.g., Cologuard) }\end{array}$ & $\begin{array}{l}\text { Every } 10 \text { years } \\
\text { Every } 5 \text { years } \\
\text { Annually } \\
\text { Annually } \\
\text { Every } 5 \text { years } \\
\text { Every } 1 \text { to } 3 \text { years }\end{array}$ \\
\hline Lung & $\begin{array}{l}\text { Age } 50-80 \text { years with a } 20 \text { pack-year smoking } \\
\text { history and have smoked within the past } 15 \text { years }\end{array}$ & $\begin{array}{l}\text { Low-dose computed tomography (CT) of } \\
\text { the chest }\end{array}$ & $\begin{array}{l}\text { Annually (until the individual has } \\
\text { not smoked within } 15 \text { years) }\end{array}$ \\
\hline
\end{tabular}

apatient population refers to those individuals for whom the USPSTF has provided an A- or B-level recommendation for screening. Other patient sub-populations, based on personal and family history, can also benefit from screenings 


\section{Conceptual Framework for ED-based Cancer Screening Interventions}

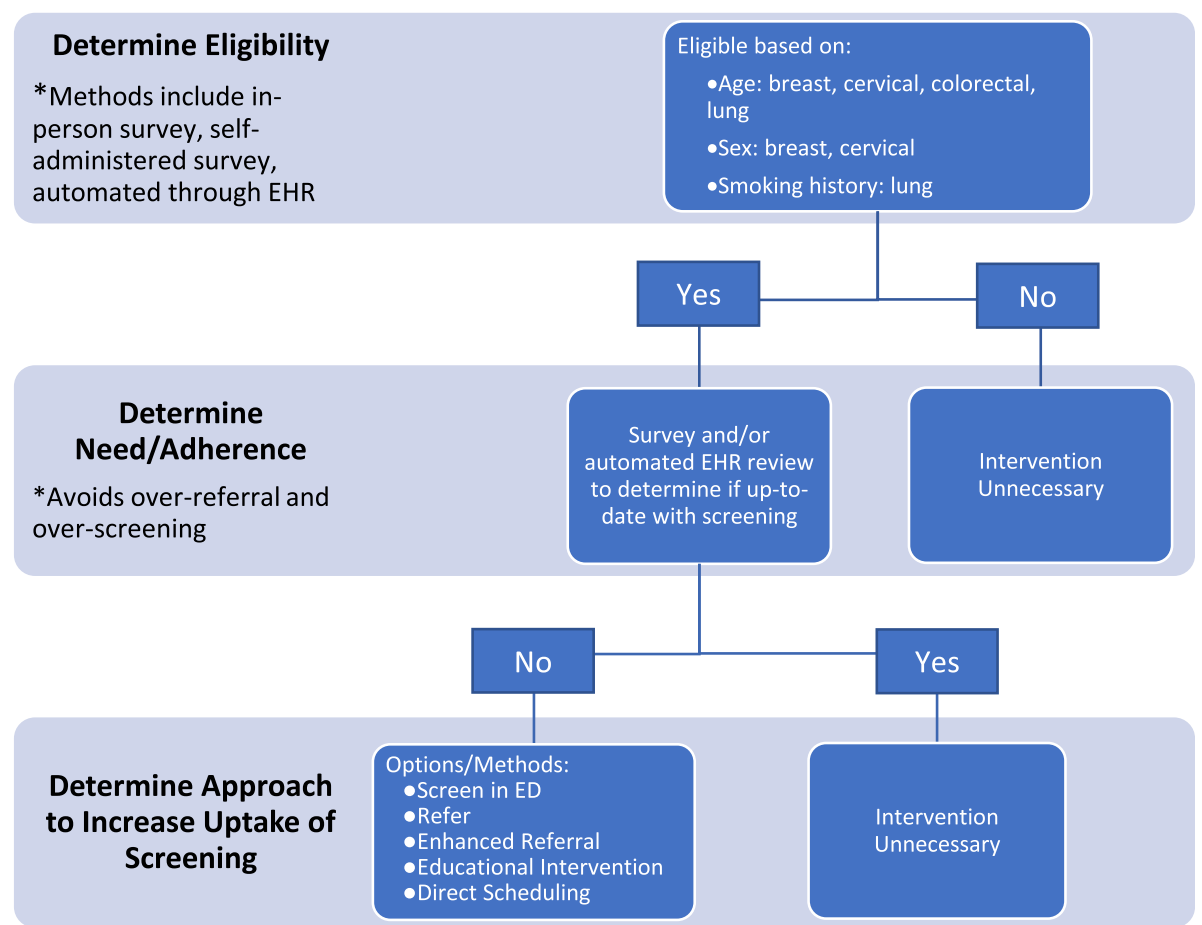

Fig. 1 Conceptual framework for ED-based cancer screening interventions

$[72,75]$. Many of these investigations, however, reported significant challenges to patient follow-up after Pap testing. Self-sampling to obtain cervico-vaginal specimens for high-risk HPV testing has been demonstrated to be acceptable among ED patients [77], but result notification and arranging subsequent care remain a challenge. Cancer screening of all types is more than just a testing procedure-it is a process that requires follow-up and, when needed, subsequent testing or treatment to address abnormal findings. Any in-ED approach to cancer screening would need to be linked with a follow-up process in order to be successful.

\section{Educational interventions}

Patient knowledge and beliefs about cancer screening have a significant impact on screening behavior. Surveys of ED patients have identified poor overall knowledge regarding cancer screening tests [66, 78, 79]. Not surprisingly, decreased knowledge is associated with lower levels of education and under-insurance [79-81] - some of the same risk factors for non-adherence with cancer screening recommendations. One study found that $74 \%$ of women undergoing pelvic examination in the ED believed that they had had a Pap test [82]. Another found that poor knowledge about cancer screening was a stronger predictor of screening adherence than race [3].
Despite the importance of knowledge and beliefs on screening uptake, a paucity of work has been done to investigate the impact of ED-based educational interventions. In one study, health promotion nurses discussed cervical cancer screening with ED patients who selfidentified as requiring screening, resulting in nearly half obtaining Pap testing during the study follow-up period after ED discharge [71]. Another study, comparing the impact of a simple brochure versus in-person education and motivational interviewing among ED waiting room patients, found no difference in mammography uptake at 3 months [64].

\section{Simple referral}

Given the challenges to conducting cancer screening procedures in the ED itself, a number of interventions have aimed to facilitate cancer screening after ED discharge for those patients who have been identified as both eligible and in need of screening. Interventions consisting of simple referral (i.e., without extended contact aimed at reinforcing the encouragement to get screened) have had modest results. A breast cancer screening referral program that identified over 2500 ED patients in need of screening found that only 159 (6\%) had completed the exam upon follow-up [76]. In an Urgent Care-based study of referral for cervical cancer screening, $29 \%$ of women had obtained the test at study 
follow-up [72]. One-month screening uptake rates for an ED-based study using a simple referral for patients in need of breast or cervical cancer screening were $8.3 \%$ and $10.2 \%$, respectively [83]. In a study that evaluated the efficacy of making a next-day mammogram appointment for eligible ED patients, $38 \%$ of enrolled patients completed the screening [84]. It is notable that even with next-day appointments, a feat not likely feasible in many healthcare systems, most patients did not obtain screening. Although there is meager literature describing EDbased referral interventions for cancer screening, these results suggest that there is likely room to improve upon the results of simple referral.

\section{Enhanced referral}

A specific challenge of ED-based interventions is that longitudinal relationships are not built between ED providers and patients. Interventions are generally limited to the single ED index visit. The limited success of interventions based on a simple referral to promote uptake of cancer screening underscores this challenge. In an effort to extend an ED-based intervention beyond the index visit with the purpose of reinforcing and augmenting a referral, a text-message-based intervention was evaluated in a randomized controlled pilot study [15]. A series of text messages that included referral links as well as content grounded in behavioral change theory were sent to enrolled patients in an effort to increase uptake of cervical cancer screening. Uptake at follow-up was increased among those receiving text messages 19\% relative to the control group (simple referral). This approach is currently being evaluated in a larger NIH-funded trial [70]. Texting or other mobile health ("mHealth") approaches have the potential to reinforce and enhance the efficacy of interventions initiated in the ED.

\section{Other approaches}

A number of potential approaches to increasing uptake of cancer screening among ED patients have yet to be explored. System-based interventions such as linkage of ED patients with patient navigator programs, "smart" electronic health records that flag patients in need of screening and automate referral, and integration of the ED as an intentional portal of entry into a system integrated model of care, all have some potential to improve screening rates among ED patients. For any approach to succeed, it must first effectively identify eligible patients who are in need of screening, address their knowledge and beliefs regarding screening, and connect them with screening services through which subsequent follow-up and care pathways are established.

\section{Additional considerations regarding ED-based cancer screening}

Interventions to promote cancer screenings that are not recommended by the USPSTF, including skin, ovarian, prostate, thyroid, pancreatic, testicular, bladder, and oral cancer, have not been evaluated in the emergency medicine setting. However, substantial literature exists on hepatitis screening in the ED-especially hepatitis C [85]. While USPSTF does have a set of grade A and B screening recommendations related to viral hepatitis, these recommendations are not specifically designated as cancer screenings. Although most people infected with hepatitis B or C do not develop hepatic cancer, $65 \%$ of hepatic cancer in the USA is related to these infections [86]. Given the recent treatment advances for hepatitis $\mathrm{C}$, and the associated risk factors that are disproportionately represented among ED patients (e.g., older age, dialysis, injection drug use), hepatitis $\mathrm{C}$ screening has demonstrated promise with both targeted and untargeted screening interventions among ED patients [87-89].

One of the challenges of cancer screening in any setting is following up with patients that have abnormal results in order to conduct additional diagnostic or treatment procedures. The precise barriers to care that are disproportionately experienced by ED patients also put them at risk for being lost to follow-up for cancer screenings conducted in other healthcare settings. Some of the interventions described above that are aimed at initiating cancer screening with ED patients could conceivably be adapted to identify ED patients with extant abnormal screening exam results and intervene to reestablish their care in order to take the next steps in their evaluation or treatment.

Finally, incidental identification of cancer or suspected cancer is a routine occurrence in the ED setting. ED care involves extensive use of advanced imaging that generates findings suspicious for malignancy that are often unrelated to the test indications [90]. While the approach to follow up for these incidental findings is an important and challenging issue in emergency medicine, it is distinct from cancer screening which is an intentional evidenced-based approach to detect cancer or pre-cancerous lesions before they become symptomatic.

\section{Knowledge gaps and research opportunities}

Despite its potential, relatively little work has been done exploring the use of the ED environment to promote the uptake of cancer screening. Knowledge gaps and research opportunities are wide ranging and all of the methods described above merit further investigation. Refined approaches to in-ED screening might still find success relative to prior work. The use of mHealth methods to sustain contact with ED patients is only now being explored in depth. ED-adjacent care settings, such as 
urgent care centers and observation units, may hold promise in promoting cancer screening. Given the essential first step of systematically identifying patients with screening needs, EHR-automated or selfadministered survey methods require further exploration. Importantly, the validity of survey measures for self-report of screening is important and refinement of these measures may be needed.

While development of health system models of care is a task that extends far beyond the ED, intentional integration of the ED into the cancer screening programs of over-arching models of care has the potential to engage hard-to-reach groups into these programs. Effective approaches to linking ED patients to local screening resources, including cancer screening navigation programs, are also needed. There may be opportunities to link more established ED-based interventions (e.g., smoking cessation) with cancer screening (e.g., lung cancer screening). In all cases, cost-effectiveness of proposed interventions would need to be explored.

Another important knowledge gap is how to best engage sexual and gender minorities in ED-based cancer screening. Sexual and gender minority persons, including nonbinary and transgender persons, experience significant healthcare disparities [91] and are at increased risk for some cancers [92]. Cancer screening may pose a particular challenge among these groups as identifying individual screening needs relies in part on data sources that may fail to identify them accurately [93]. Cancer screening (e.g., cervical cancer) should be based on anatomy; however, healthcare providers often lack knowledge and effective communication skills related to transgender and other sexual and gender minority patients' health [94]. Engaging these groups in cancer screening research is essential to addressing disparities and improving their care.

\section{Conclusion}

Millions of patients in need of recommended cancer screenings are cared for in emergency departments every year in the USA, many of whom experience barriers to care and are difficult to reach through other healthcare settings. This makes the ED setting uniquely positioned to address disparities in cancer screening uptake and contribute to progress towards national cancer screening goals. To be effective, interventions that aim to achieve this purpose must identify patients with screening needs, engage with patients regarding their knowledge and beliefs about screening, and provide an effective method to conduct or connect patients with screening procedures and subsequent follow-up. Overall, there has been a paucity of research on interventions to improve cancer screening uptake among ED patients. However, a number of approaches have been explored in early stages and some promising avenues are actively under investigation.

\section{Abbreviations}

CRC: Colorectal cancer; ED: Emergency department; EHR: Electronic health record; FIT: Fecal immunochemical test; FOBT: Fecal occult blood test; HPV: Human papillomavirus; NHIS: National Health Interview Survey; Pap: Papanicolaou; USPSTF: United States Preventive Services Task Force

\section{Acknowledgements}

Collaboration among authors was facilitated through the $\mathrm{NCl}$-supported Comprehensive Oncologic Emergencies Research Network (CONCERN). The content is solely the responsibility of the authors and does not necessarily represent the official views of CONCERN, the National Cancer Institute, or the National Institutes of Health.

\section{Authors' contributions}

DA conceived of the overall purpose and structure of the manuscript. BA and EC contributed to the manuscript writing and critical editing. All authors read and approved the final manuscript.

\section{Funding}

None

Availability of data and materials

Not applicable

\section{Declarations}

Ethics approval and consent to participate

Not applicable.

Consent for publication

Not applicable.

\section{Competing interests}

The authors declare that they have no competing interests.

\section{Author details}

1Department of Emergency Medicine, University of Rochester, 601 Elmwood Avenue, Box 655C, Rochester, NY 14642, USA. ${ }^{2}$ Department of Epidemiology, University of Texas MD Anderson Cancer Center, Unit 1340, PO Box 301439, Houston, TX 77230-1439, USA.

Received: 13 January 2022 Accepted: 4 February 2022

Published online: 24 February 2022

\section{References}

1. White A, Thompson TD, White MC, Sabatino SA, de Moor J, Doria-Rose PV, Geiger AM, Richardson LC. Cancer screening test use - United States, 2015. MMWR Morb Mortal Wkly Rep. 2017;66(8):201-6. https://doi.org/10.15585/ mmwr.mm6608a1.

2. Ginde AA, Millen JC, Love JS, Pang JM, Camargo CA Jr. Compliance with recommended cancer screening among emergency department patients: a multicenter survey. Acad Emerg Med. 2008;15(5):483-6. https://doi.org/1 0.1111/j.1553-2712.2008.00103.x.

3. Paskett ED, Rushing J, D'Agostino R Jr, Tatum C, Velez R. Cancer screening behaviors of low-income women: the impact of race. Womens Health. 1997; 3(3-4):203-26.

4. Smith RA, Andrews KS, Brooks D, Fedewa SA, Manassaram-Baptiste D, Saslow D, Wender RC. Cancer screening in the United States, 2019: a review of current American Cancer Society guidelines and current issues in cancer screening. CA Cancer J Clin. 2019;69(3):184-210. https://doi.org/10.3322/caa c.21557

5. Beavis AL, Gravitt PE, Rositch AF. Hysterectomy-corrected cervical cancer mortality rates reveal a larger racial disparity in the United States. Cancer. 2017. https://doi.org/10.1002/cncr.30507.

6. Haddad DN, Sandler KL, Henderson LM, Rivera MP, Aldrich MC. Disparities in lung cancer screening: a review. Ann Am Thorac Soc. 2020;17(4):399-405. https://doi.org/10.1513/AnnalsATS.201907-556CME.

7. Japuntich SJ, Krieger NH, Salvas AL, Carey MP. Racial disparities in lung cancer screening: an exploratory investigation. J Natl Med Assoc. 2018; 110(5):424-7. https://doi.org/10.1016/j.jnma.2017.09.003. 
8. Martin AN, Hassinger TE, Kozower BD, Camacho F, Anderson RT, Yao N. Disparities in lung cancer screening availability: lessons from Southwest Virginia. Ann Thorac Surg. 2019;108(2):412-6. https://doi.org/10.1016/j.athora csur.2019.03.003.

9. Sin MK. Lung cancer disparities and African-Americans. Public Health Nurs. 2017:34(4):359-62. https://doi.org/10.1111/phn.12335.

10. Sabatino SA, Thompson TD, White MC, Shapiro JA, de Moor J, Doria-Rose VP, Clarke T, Richardson LC. Cancer screening test receipt - United States, 2018. MMWR Morb Mortal Wkly Rep. 2021;70(2):29-35. https://doi.org/10.1 5585/mmwr.mm7002a1.

11. Abar B, Dalawari P, Ogedegbe C, Santoro-Terray L, Adler D, Bradley K. Identifying cancer screening adherence in the emergency department utilizing research associates. J Emerg Med. 2020;59(6):894-9. https://doi. org/10.1016/j.jemermed.2020.07.013.

12. Molina $Y$, Silva A, Rauscher GH. Racial/ethnic disparities in time to a breast cancer diagnosis: the mediating effects of health care facility factors. Med Care. 2015;53(10):872-8. https://doi.org/10.1097/MLR. 0000000000000417.

13. Sabatino SA, White MC, Thompson TD, Klabunde CN. Centers for Disease C, Prevention. Cancer screening test use - United States, 2013. MMWR Morb Mortal Wkly Rep. 2015;64(17):464-8.

14. Brown ML, Klabunde CN, Cronin KA, White MC, Richardson LC, McNeel TS. Challenges in meeting Healthy People 2020 objectives for cancer-related preventive services, National Health Interview Survey, 2008 and 2010. Prev Chronic Dis. 2014;11:E29.

15. Adler D, Abar B, Wood N, Bonham A. An intervention to increase uptake of cervical cancer screening among emergency department patients: results of a randomized pilot study. J Emerg Med. 2019;57(6):836-43. https://doi.org/1 0.1016/j.jemermed.2019.07.021

16. Garcia TC, Bernstein AB, Bush MA. Emergency department visitors and visits: who used the emergency room in 2007? NCHS Data Brief. 2010;38:1-8.

17. Yee AM, Mazumder PK, Dong F, Neeki MM. Impact of healthcare access disparities on initial diagnosis of breast cancer in the emergency department. Cureus. 2020;12(8):e10027. https://doi.org/10.7759/cureus.10027.

18. Niska R, Bhuiya F, Xu J. National Hospital Ambulatory Medical Care Survey: 2007 emergency department summary. Natl Health Stat Rep. 2010;6(26):1-31

19. National Hospital Ambulatory Medical Care Survey: 2011 Emergency Department Summary Tables. Centers for Disease Control \& Prevention. Available at https://www.cdc.gov/nchs/data/ahcd/nhamcs_emergency/2 011_ed_web_tables.pdf.

20. Limmer K, LoBiondo-Wood G, Dains J. Predictors of cervical cancer screening adherence in the United States: a systematic review. J Adv Practitioner Oncol. 2014;5(1):31-41.

21. Rhodes KV, Gordon JA, Lowe RA. Preventive care in the emergency department, part I: clinical preventive services - are they relevant to emergency medicine? Acad Emerg Med. 2000;7(9):1036-41. https://doi.org/1 0.1111/j.1553-2712.2000.tb02097.x

22. Service USPH. The clinician's handbook of preventive services. 2 nd ed. Germantown, MD: International Publishing; 1998.

23. Cairns C, Ashman JJ, Kang K. Emergency department visit rates by selected characteristics: United States, 2018. NCHS Data Brief. 2021;(401):1-8.

24. Irvin CB, Wyer PC, Gerson LW. Preventive care in the emergency department, part II: clinical preventive services — an emergency medicine evidence-based review. Acad Emerg Med. 2000;7(9):1042-54. https://doi. org/10.1111/j.1553-2712.2000.tb02098.x.

25. D'Onofrio G, Degutis LC. Preventive care in the emergency department: screening and brief intervention for alcohol problems in the emergency department: a systematic review. Acad Emerg Med. 2002;9(6):627-38. https://doi.org/10.1197/aemj.9.6.627.

26. Bernstein SL, Becker BM. Preventive care in the emergency department: diagnosis and management of smoking and smoking-related illness in the emergency department: a systematic review. Acad Emerg Med. 2002;9(7): 720-9. https://doi.org/10.1197/aemj.9.7.720.

27. Bernstein E, Bernstein J, Levenson S. Project ASSERT: an ED-based intervention to increase access to primary care, preventive services, and the substance abuse treatment system. Ann Emerg Med. 1997;30(2):181-9. https://doi.org/10.1016/S0196-0644(97)70140-9.

28. Lemhoefer C, Rabe GL, Wellmann J, Bernstein SL, Cheung KW, McCarthy WJ, et al. Emergency department-initiated tobacco control: update of a systematic review and meta-analysis of randomized controlled trials. Prev Chronic Dis. 2017;14:E89.
29. McGinnes RA, Hutton JE, Weiland TJ, Fatovich DM, Egerton-Warburton D. Review article: effectiveness of ultra-brief interventions in the emergency department to reduce alcohol consumption: a systematic review. Emerg Med Australas. 2016;28(6):629-40. https://doi.org/10.1111/1742-6723.12624.

30. Zucker J, Cennimo D, Sugalski G, Swaminthan S. Identifying areas for improvement in the HIV screening process of a high-prevalence emergency department. AIDS Patient Care STDs. 2016;30(6):247-53. https://doi.org/10.1 089/apc.2016.0068.

31. Moyer VA. Screening for cervical cancer: US Preventive Services Task Force recommendation statement. Ann Int Med. 2012;156(12):880-91. https://doi. org/10.7326/0003-4819-156-12-201206190-00424.

32. Siu AL. Force USPST. Screening for breast cancer: U.S. Preventive Services Task Force Recommendation Statement. Ann Intern Med. 2016;164(4):279_ 96. https://doi.org/10.7326/M15-2886

33. Force USPST, Bibbins-Domingo K, Grossman DC, Curry SJ, Davidson KW, Epling JW Jr, et al. Screening for colorectal cancer: US Preventive Services Task Force Recommendation Statement. JAMA. 2016:315(23):2564-75. https://doi.org/10.1001/jama.2016.5989.

34. Force USPST, Krist AH, Davidson KW, Mangione CM, Barry MJ, Cabana M, et al. Screening for lung cancer: US Preventive Services Task Force Recommendation Statement. JAMA. 2021;325(10):962-70. https://doi.org/1 0.1001/jama.2021.1117

35. Zahnd WE, Eberth JM. Lung cancer screening utilization: a behavioral risk factor surveillance system analysis. Am J Prev Med. 2019;57(2):250-5. https:// doi.org/10.1016/j.amepre.2019.03.015.

36. US Department of Health and Human Services Office of Disease Prevention and Health Promotion. Healthy People 2020. Available at http://www.hea Ithypeople.gov/.

37. US Department of Health and Human Services Office of Disease Prevention and Health Promotion. Healthy People 2030. Available at https://health.gov/ healthypeople.

38. Miles RC, Flores EJ, Lopez DB, Sohn YJ, Gillis EA, Lehman CD, Narayan AK. Leveraging emergency department encounters to improve cancer screening adherence. J Am Coll Radiol. 2021;18(6):834-40. https://doi.org/1 0.1016/j.jacr.2020.12.025.

39. Richardson LC, Henley SJ, Miller JW, Massetti G, Thomas CC. Patterns and trends in age-specific black-white differences in breast cancer incidence and mortality-United States, 1999-2014. Morb Mortal Wkly Rep. 2016;65(40): 1093-8. https://doi.org/10.15585/mmwr.mm6540a1.

40. Suvielllance $E$, and End Results Program. Cancer stat facts: female breast cancer 2021 [Available from: https://seer.cancer.gov/statfacts/html/breast.html.

41. Force UPST. Screening for breast cancer: US Preventive Services Task Force recommendation statement. Ann Int Med. 2009;151(10):716-236. https://doi. org/10.7326/0003-4819-151-10-200911170-00008

42. Bradley CJ, Given CW, Roberts C. Race, socioeconomic status, and breast cancer treatment and survival. J Natl Cancer Inst. 2002;94(7):490-6. https://doi.org/10.1093/jnci/94.7.490.

43. Van Ravesteyn NT, Schechter CB, Near AM, Heijnsdijk EA, Stoto MA, Draisma $\mathrm{G}$, et al. Race-specific impact of natural history, mammography screening, and adjuvant treatment on breast cancer mortality rates in the United States. Cancer Epidemiol Prev Biomark. 2011;20(1):112-22. https://doi.org/1 0.1158/1055-9965.EPI-10-0944.

44. Society AC. Cancer facts \& figures 2020. In: Society. AC, editor. Atlanta, GA; 2020

45. Robinson M, Hardcastle J, Moss S, Amar S, Chamberlain J, Armitage N, et al. The risks of screening: data from the Nottingham randomised controlled trial of faecal occult blood screening for colorectal cancer. Gut. 1999:45(4): 588-92. https://doi.org/10.1136/gut.45.4.588.

46. Kronborg O, Fenger C, Olsen J, Jørgensen OD, Søndergaard O. Randomised study of screening for colorectal cancer with faecal-occult-blood test. Lancet. 1996;348(9040):1467-71. https://doi.org/10.1016/S0140-6736(96)0343 0-7.

47. Zauber AG, Winawer SJ, O'Brien MJ, Lansdorp-Vogelaar I, van Ballegooijen M, Hankey BF, Shi W, Bond JH, Schapiro M, Panish JF, Stewart ET, Waye JD. Colonoscopic polypectomy and long-term prevention of colorectal-cancer deaths. N Engl J Med. 2012;366(8):687-96. https://doi.org/10.1056/NEJMoa11 00370.

48. Zauber A, Knudsen A, Rutter CM, Lansdorp-Vogelaar I, Kuntz KM. Evaluating the benefits and harms of colorectal cancer screening strategies: a collaborative modeling approach. Agency for Healthcare Research and Quality: Rockville, MD; 2015. 
49. Bibbins-Domingo K, Grossman DC, Curry SJ, Davidson KW, Epling JW, García FA, et al. Screening for colorectal cancer: US Preventive Services Task Force recommendation statement. Jama. 2016;315(23):2564-75. https://doi.org/1 0.1001/jama.2016.5989.

50. Bray C, Bell LN, Liang H, Collins D, Yale SH. Colorectal cancer screening. Wmj. 2017;116(1):27-33.

51. Bosch LJW, Melotte V, Mongera S, Daenen KLJ, Coupé VMH, van Turenhout ST, Stoop EM, de Wijkerslooth TR, Mulder CJJ, Rausch C, Kuipers EJ, Dekker E, Domanico MJ, Lidgard GP, Berger BM, van Engeland M, Carvalho B, Meijer GA. Multitarget stool DNA test performance in an average-risk colorectal cancer screening population. Am J Gastroenterol. 2019;114(12):1909-18. https://doi.org/10.14309/ajg.0000000000000445.

52. Liss DT, Baker DW. Understanding current racial/ethnic disparities in colorectal cancer screening in the United States: the contribution of socioeconomic status and access to care. Am J Prev Med. 2014;46(3):22836. https://doi.org/10.1016/j.amepre.2013.10.023.

53. Jerant AF, Fenton JJ, Franks P. Determinants of racial/ethnic colorectal cancer screening disparities. Arch Int Med. 2008;168(12):1317-24. https://doi. org/10.1001/archinte.168.12.1317.

54. Ito Fukunaga M, Wiener RS, Slatore CG. The 2021 US Preventive Services Task Force recommendation on lung cancer screening: the more things stay the same. JAMA Oncol. 2021. https://doi.org/10.1001/jamaoncol.2020.8376.

55. Moyer VA. Force USPST. Screening for lung cancer: U.S. Preventive Services Task Force recommendation statement. Ann Intern Med. 2014;160(5):330-8. https://doi.org/10.7326/M13-2771.

56. Criss SD, Cao P, Bastani M, Ten Haaf K, Chen Y, Sheehan DF, et al. Costeffectiveness analysis of lung cancer screening in the United States: a comparative modeling study. Ann Intern Med. 2019;171(11):796-804. https://doi.org/10.7326/M19-0322.

57. de Koning HJ, van der Aalst CM, de Jong PA, Scholten ET, Nackaerts K, Heuvelmans MA, Lammers JWJ, Weenink C, Yousaf-Khan U, Horeweg N, van 't Westeinde S, Prokop M, Mali WP, Mohamed Hoesein FAA, van Ooijen PMA, Aerts JGJV, den Bakker MA, Thunnissen E, Verschakelen J, Vliegenthart R, Walter JE, ten Haaf K, Groen HJM, Oudkerk M. Reduced lung-cancer mortality with volume $C T$ screening in a randomized trial. N Engl J Med. 2020;382(6):503-13. https://doi.org/10.1056/NEJMoa1911793.

58. National Lung Screening Trial Research T, Aberle DR, Adams AM, Berg CD, Black WC, Clapp JD, et al. Reduced lung-cancer mortality with low-dose computed tomographic screening. N Engl J Med. 2011;365(5):395-409. https://doi.org/10.1056/NEJMoa1102873.

59. Siegel RL, Miller KD, Jemal A. Cancer statistics, 2019. CA Cancer J Clin. 2019; 69(1):7-34. https://doi.org/10.3322/caac.21551.

60. Rivera MP, Katki HA, Tanner NT, Triplette M, Sakoda LC, Wiener RS, Cardarelli R, Carter-Harris L, Crothers K, Fathi JT, Ford ME, Smith R, Winn RA, Wisnivesky JP, Henderson LM, Aldrich MC. Addressing disparities in lung cancer screening eligibility and healthcare access. An Official American Thoracic Society Statement. Am J Respir Crit Care Med. 2020;202(7):e95e112. https://doi.org/10.1164/rccm.202008-3053ST.

61. USPSTF. Draft recommendation statement | Lung cancer: screening. US Preventive Services Task Force. 2020.

62. Carlos RC, Fendrick AM. Improving cancer screening adherence: using the "teachable moment" as a delivery setting for educational interventions. Am J Manag Care. 2004;10(4):247-8.

63. Llovera I, Ward MF, Ryan JG, LaTouche T, Sama A. A survey of the emergency department population and their interest in preventive health education. Acad Emerg Med. 2003;10(2):155-60. https://doi.org/10.1197/a emj.10.2.155.

64. Hatcher J, Rayens MK, Schoenberg NE. Mammography promotion in the emergency department: a pilot study. Public Health Nurs. 2010;27(6):520-7. https://doi.org/10.1111/j.1525-1446.2010.00894.x.

65. Orlando MS, Rothman RE, Woodfield A, Gauvey-Kern M, Peterson S, Miller T, Hill PM, Gaydos CA, Hsieh YH. Public health information delivery in the emergency department: analysis of a kiosk-based program. J Emerg Med. 2016;50(2):223-7. https://doi.org/10.1016/j.jemermed.2015.06.075.

66. Hatcher-Keller J, Rayens MK, Dignan M, Schoenberg N, Allison P. Beliefs regarding mammography screening among women visiting the emergency department for nonurgent care. J Emerg Nurs. 2014;40(2):e27-35. https:// doi.org/10.1016/j.jen.2013.01.015.

67. Delgado MK, Acosta CD, Ginde AA, Wang NE, Strehlow MC, Khandwala YS, et al. National survey of preventive health services in US emergency departments. Ann Emerg Med. 2011;57(2):104-8. e2.
68. Lowe RA, Berlin M. Pap smears in a public hospital emergency department: a failure of the system. Ann Emerg Med. 1992;21(8):982-4. https://doi.org/1 0.1016/S0196-0644(05)82939-7.

69. Abar B, Dylla L, Sergeant M, Pasternack J, Adler D. Assessing adherence with preventive screening recommendations among ED patients: piloting an effective use of wait time. Am J Emerg Med. 2018;36(6):1105-6. https://doi. org/10.1016/j.ajem.2017.09.053.

70. Adler D, Abar B, Bonham A, Fiscella K, Mustian K, Chamberlin S. Increasing cervical cancer screening uptake among emergency department patients. NIH National Cancer Institute (R01CA246626). 2020. https://reporter.nih.gov/ search/IGNwWGaOjkq5X-blyixh-Q/project-details/10049446.

71. Cummings GE, Francescutti LH, Predy G, Cummings G. Health promotion and disease prevention in the emergency department: a feasibility study. CJEM. 2006;8(2):100-5. https://doi.org/10.1017/\$1481803 500013543

72. Batal H, Biggerstaff S, Dunn T, Mehler PS. Cervical cancer screening in the urgent care setting. J Gen Intern Med. 2000;15(6):389-94. https://doi.org/1 0.1046/j.1525-1497.2000.08001.x.

73. Devine AS, Mason J, Rankins N, Favor TT, Baur V, Parker R, Baddorf S, McCarthy M, Ford L, Cunningham TD. A model for the implementation of cervical cancer screening and human papillomavirus vaccination in the ED: a pilot study. Am J Emerg Med. 2016;34(3):648. https://doi.org/10.1016/j.a jem.2015.12.022

74. Dunn TS, Jazbec A, Awad R, Batal H. Papanicolaou screening in an urgent care setting. Am J Obstet Gynecol. 2005;192(4):1084-6. https://doi.org/10.1 016/j.ajog.2004.09.030

75. Hogness CG, Engelstad LP, Linck LM, Schorr KA. Cervical cancer screening in an urban emergency department. Ann Emerg Med. 1992;21(8):933-9. https://doi.org/10.1016/S0196-0644(05)82931-2.

76. Mandelblatt J, Freeman H, Winczewski D, Cagney K, Williams S, Trowers R, et al. Implementation of a breast and cervical cancer screening program in a public hospital emergency department. Cancer Control Center of Harlem. Ann Emerg Med. 1996;28(5):493-8. https://doi.org/10.1016/S0196-0644 (96)70111-7.

77. Montealegre JR, Landgren RM, Anderson ML, Hoxhaj S, Williams S, Robinson DJ, Scheurer ME, Ramondetta LM. Acceptability of self-sample human papillomavirus testing among medically underserved women visiting the emergency department. Gynecol Oncol. 2015;138(2):317-22. https://doi. org/10.1016/j.ygyno.2015.05.028.

78. Merchant RC, Gee EM, Bock BC, Becker BM, Clark MA. Negative opinions about cancer screening and contraceptive measures by female emergency department patients. J Prim Prev. 2008;29(6):517-33. https://doi.org/10.1007/ s10935-008-0154-8.

79. Merchant RC, Gee EM, Bock BC, Becker BM, Clark MA. Correlates of women's cancer screening and contraceptive knowledge among female emergency department patients. BMC Womens Health. 2007;7(1):7. https://doi.org/10.11 86/1472-6874-7-7

80. Takakuwa KM, Ernst AA, Weiss SJ, Nick TG. Breast cancer knowledge and preventive behaviors: an urban emergency department-based survey. Acad Emerg Med. 2000;7(12):1393-8. https://doi.org/10.1111/j.1553-2712.2000.tb00497x.

81. Carter J, Park ER, Moadel A, Cleary SD, Morgan C. Cancer knowledge, attitudes, beliefs, and practices (KABP) of disadvantaged women in the South Bronx. J Cancer Educ. 2002;17(3):142-9.

82. Lyons MS, Lindsell CJ, Trott AT. Emergency department pelvic examination and Pap testing: addressing patient misperceptions. Acad Emerg Med. 2004; 11(4):405-8. https://doi.org/10.1111/j.1553-2712.2004.tb01462.x.

83. Zun LS, Downey L. Adult health screening and referral in the emergency department. South Med J. 2006;99(9):940-8. https://doi.org/10.1097/01.smj. 0000224130.29337.19.

84. Bernstein J, Mutschler P, Bernstein E. Keeping mammography referral appointments: motivation, health beliefs, and access barriers experienced by older minority women. J Midwifery Womens Health. 2000:45(4):308-13. https://doi.org/10.1016/\$1526-9523(00)00037-4.

85. Gardona RGB, Barbosa DA, Ferraz MLG. Screening for hepatitis $C$ in urgent and emergency units: a systematic review. Rev Esc Enferm USP. 2020;54 e03611. https://doi.org/10.1590/s1980-220×20180450-03611.

86. Sheet CF. Viral hepatitis and liver cancer; 2016.

87. Cowan EA, Dinani A, Brandspiegel S, O'Brien-Lambert C, Zaheer J, Eiting E, Loo G, Calderon Y. Nontargeted hepatitis C screening in an urban emergency department in New York City. J Emerg Med. 2021;60(3):299-309. https://doi.org/10.1016/j.jemermed.2020.09.034. 
88. Mendlowitz AB, Naimark D, Wong WWL, Capraru C, Feld JJ, Isaranuwatchai W, Krahn M. The emergency department as a setting-specific opportunity for population-based hepatitis C screening: an economic evaluation. Liver Int. 2020;40(6):1282-91. https://doi.org/10.1111/liv.14458.

89. Ragan K, Pandya A, Holotnak T, Koger K, Collins N, Swain MG. Hepatitis C virus screening of high-risk patients in a Canadian emergency department. Can J Gastroenterol Hepatol. 2020;2020:5258289-6. https://doi.org/10.1155/2 020/5258289.

90. Ruesseler M, Schill A, Lehnert T, Wyen H, Wutzler S, Marzi I, Walcher F. Incidental findings in patients with multiple injuries: how to proceed? J Trauma Acute Care Surg. 2013;75(5):848-53. https://doi.org/10.1097/TA. Ob013e3182a925b9.

91. Gonzales G, Henning-Smith C. Health disparities by sexual orientation: results and implications from the behavioral risk factor surveillance system. J Community Health. 2017;42(6):1163-72. https://doi.org/10.1007/s10900-0170366-z.

92. The LO. Cancer risk in the transgender community. Lancet Oncol. 2015; 16(9):999. https://doi.org/10.1016/S1470-2045(15)00249-1.

93. Grasso C, Goldhammer H, Funk D, King D, Reisner SL, Mayer KH, Keuroghlian AS. Required sexual orientation and gender identity reporting by US health centers: first-year data. Am J Public Health. 2019;109(8):1111-8. https://doi.org/10.2105/AJPH.2019.305130.

94. Wheldon CW, Schabath MB, Hudson J, Bowman Curci M, Kanetsky PA, Vadaparampil ST, Simmons VN, Sanchez JA, Sutton SK, Quinn GP. Culturally competent care for sexual and gender minority patients at National Cancer Institute-designated comprehensive cancer centers. LGBT Health. 2018;5(3): 203-11. https://doi.org/10.1089/lgbt.2017.0217.

\section{Publisher's Note}

Springer Nature remains neutral with regard to jurisdictional claims in published maps and institutional affiliations.

Ready to submit your research? Choose BMC and benefit from:

- fast, convenient online submission

- thorough peer review by experienced researchers in your field

- rapid publication on acceptance

- support for research data, including large and complex data types

- gold Open Access which fosters wider collaboration and increased citations

- maximum visibility for your research: over $100 \mathrm{M}$ website views per year

At $\mathrm{BMC}$, research is always in progress.

Learn more biomedcentral.com/submissions 